\title{
EU mister interesse og indflydelse i Vestbalkan
}

\section{Daniel Korski}

Regionen keder nu EU, og missioner, der blev lanceret med store fanfarer, kører på automatpilot. Tempoet for EU-integration er blevet markant langsommere, og lokale ledere mindre reformivrige. Imens får Rusland, Tyrkiet og Kina større indflydelse i regionen

Elleve år efter den sidste store konflikt i Vestbalkan er regionen nu et udenrigspolitisk aber dabei. Kun et fåtal eksperter diskuterer fortsat regionen. Og europæiske udenrigsministre, der for nogle få år siden ville bruge timevis på at tale om Vestbalkan, fokuserer nu deres månedlige møder på mere presserende udenrigspolitiske emner som Iran, Yemen og Pakistan.

Vestbalkan er kun på dagsordenen i ny og næ, og når der endelig udstedes et kommuniké om Vestbalkan fra møderne, så lyder det mest som et diplomatisk formbrev. Regionens lande ønskes til lykke med deres fremgang, men bedes gå lidt hårdere til reformerne. Per Stig Møller skrev den 21. februar 2008, at "den sidste brik [er] på plads på det komplicerede Balkanlandkort. Grænserne ligger fast, og forudsætningen for stabilitet er til stede. Vi kan for alvor se fremad. Balkans fremtid ligger i EU." Sidste gang Vestbalkan fik rigtig opmærksomhed på Christiansborg - ud over rutinebriefinger til Udenrigspolitisk Nævn - var da borgen lagde rammer til en diskussion om 1990'ernes folkemord ti år efter, at forbrydelserne fandt sted i regionen.

Eller sagt på en anden måde: Regionen keder EU og de fleste medlemslande. Ansvaret for porteføljen er for lang tid siden blevet givet til bureaukraterne i Europa-Kommissionen, hvis opgave det primært er at fokusere på landenes forsøg på at 
tilnærme sig EU's lovsamling, og som bruger konditionalitet for at få gang i reformerne. Selv de missioner, militære såvel som civile, der i starten blev lanceret under stor fanfare med den Fælles Udenrigs- og Sikkerhedspolitik (FUSP) i 2003, kører nu på automatpilot. Sikkerhedsanalytikeren Henrik Breitenbach kalder regionen 'et geo-strategisk vandhul'.

Det er let at se regionen med disse øjne, for de sidste par år har i sandhed været mere håbefulde end mange forgangne perioder. I 1990'erne rystedes verdenssamfundet af Jugoslaviens blodige opløsning. Fra 1992 til 1995 blev der udkæmpet en voldsom krig. Etniske udrensninger, koncentrationslejre, massegrave og folkedrab var på ny i folkemunde. I eftertiden er massakren i landsbyen Srebrenica, hvor over 7.000 bosnisk muslimske drenge og mænd blev dræbt, blevet selve symbolet på den brutalitet, hvormed krigen i det tidligere Jugoslavien blev udkæmpet.

Men siden 1995, året hvor krigen i Bosnien endte, og i særdeleshed efter år 2000, da Serbiens præsident, Slobodan Milosevic, blev tvunget fra magten, og alle drømme om Storserbien endeligt blev lagt i graven, har regionen været på en rejse til Europa. I stedet for en by i krig og ruiner ligner Sarajevo mere og mere en moderne europæisk hovedstad. Men problemerne er ikke forsvundet. I Republika Srpska, den del af Bosnien hvor majoriteten af den ser- biske befolkning lever, er der på ny krav om uafhængighed eller sammenslutning med Serbien. Men kun et mindretal frygter i dag en positionskrig. Der tales sågar om helt at lukke ned for EU's fredsbevarende mission, der overtog de fredsbevarende opgaver fra NATO for fem år siden.

I Serbiens hovedstab, Beograd, hvor megen af regionens ødelæggelse i 1990 'erne blev planlagt, er en ny reformvenlig generation kommet til magten. Boris Tadic, landets pro-europæiske præsident, overleverede krigsforbryderen Radovan Karadzic til det internationale krigsforbrydertribunal i Haag - noget de titusinder af pårørende til hans mange ofre ikke troede ville ske. Tadic er desuden gået til reformer med større ildhu end sine forgængere.

På trods af spændinger mellem Serbien og Kosovo, og en endnu mere sprængfarlig situation i det serbisk dominerede Kosovo nord for Ibar-floden, tror de færreste analytikere på nye udbrud af storstilet vold. Kosovos første valg siden uafhængighedserklæringen var en opvisning i fredsommelighed, og for at forebygge eventuelle voldshandlinger har EU oprettet en politimission i Pristina.

\section{Kroatien følger snart Slovenien}

Slovenien er allerede med i EU og NATO. I 2008 bestred landet endog EU's roterende formandskab, og ef- 
ter at Ljubljanas modstand mod Kroatiens medlemskab er trukket tilbage, er Kroatien godt på vej til at blive Vestbalkans andet land i EU. Kroatien har siden oktober 2005 forhandlet om optagelse i EU, og Europa-Kommissionen har rost de fremskridt, der er sket på en række felter. Der er problemer med bl.a. korruption, serbiske flygtninges tilbagevenden, pressefrihed samt retsforfølgelse af krigsforbrydere; men hvis ikke det bliver i 2010, så forventes den nyvalgte kroatiske præsident senest i 2011 at kunne sætte sin underskrift på en indlemmelsestraktat.

For et land, der kun for ti år siden hyllede krigsforbrydere og sågar talte glorværdigt om det kroatiske fascist-regime, der under Anden Verdenskrig var Hitlertysklands allierede på Vestbalkan, er en lang rejse foretaget. I dag lader EU's største bekymring til at være den vedvarende statsstøtte til kroatiske skibsværfter, som er i strid med EU's konkurrenceregler.

Makedonien ansøgte allerede EU om medlemskab i foråret 2004. På et møde i Det Europæiske Råd den 15.-16. december 2005 blev det besluttet at anerkende Makedonien som kandidatland. Der er dog endnu ikke fastsat en dato for, hvornår de egentlige optagelsesforhandlinger kan begynde. Det har Grækenland forhindret, fordi det fortsat afviser at anerkende landet som 'Makedonien', som Athen mener at have monopol på. Derudover er sammenstød mellem slaviske makedonere og landets store albanske mindretal endnu ikke gjort til en del af fortiden. Så sent som i august 2009 angreb flere hundrede slaviske makedonere deres albanske medborgere. Ved det seneste valg i 2008 kom det også til sammenstød med dødsfald til følge.

Men implementeringen af Ohridaftalen, der satte en stopper for konflikten mellem de to folkegrupper i 2001, har forårsaget en næsten total ændring af det makedonske samfund. I dag er albanere en større del af centraladministrationen, politiet og hæren end i mange andre lande, der har haft lignende etniske stridigheder. Problemer varer ved på lokalt plan, men sammenlignet med Bosnien, der endnu ikke har implementeret tilsvarende integrationstiltag (på trods af krav herom fra Bosniens forfatningsdomstol i 2002) er samarbejdet mellem myndighederne i hovedstaden Skopje og i makedonsk-albanske partier i den albanske hovedby Tetovo imponerende.

Fremgang anes også i Albanien og Montenegro, lande der i den europæiske bevidsthed længe har været associeret med Godfatheragtige skikke og kriminalitet. Montenegro, det lille land, der oprindelig var en af Serbiens våbenbrødre og stod for bombardementet af havnebyen Dubrovnik, løsrev sig fra Beograds favntag i 2006. Efter nogle år med uafhængighed (og på trods af den stigende økonomiske indflydelse fra 
russiske finansfolk) har landet taget de første spæde skridt mod EU-medlemskab. I slutningen af 2008 ansøgte regeringen i Podgorica herom. Som et tegn på landets uafhængige udenrigspolitik anerkendte Montenegros regering sågar Kosovos uafhængighed - et modigt skridt i betragtning af Serbiens position.

I den måske hidtil største triumf for landets internationale image lagde Montenegro kulisse til James Bond-filmen Casino Royal. Filmen var optaget langt fra Vestbalkan og scenerne lignede mere Monte Carlo end Montenegro, men det faktum, at landet plausibelt kunne fremstilles som en legeplads for millionærer og glamourmodeller, er i sig selv imponerende.

Syd for, i Albanien - et land, der under kommunistleder Enver Hoxha gennemlevede et værre diktatur end nogen af de tidligere jugoslaviske republikker, og som styrtede i den økonomiske afgrund et par år efter kommuniststyrets fald, da en række investeringsfonde gik rabundus blæser der også nye vinde. Landet er i dag medlem af NATO og deltager i ISAF-missionen i Afghanistan med flere hundrede soldater.

I slutningen af 2009 bad EU's medlemslande Europa-Kommissionen om at vurdere, hvorvidt landet er parat til at indgå i forhandlinger med EU om en eventuel optagelse. Senere på året forventes det af mange, at EU vil lempe for visum-reglerne, så albanere lettere kan rejse ind i EU. Problemer er der imidlertid stadigvæk nok af. Der hersker tvivl om landets økonomiske situation og hvis Grækenland går fallit vil det få store konsekvenser i Albanien. Regeringen har et hav af ubetalte regninger, den skubber foran sig, bl.a. for mange af kostbare infrastrukturprojekter, der blev forceret igennem før sidste parlamentsvalg. Men landet oplevede i 2009 at have Europas største vækst og officielt forudser Den Internationale Valutafond en vækst på 2,2 pct. i 2010.

\section{Længe leve Jugosfæren}

Hvis man ser på regionen som helhed, er der også mange bemærkelsesværdige eksempler på fremgang. I dag er mordraten lavere i Serbien end i Frankrig, Polen, Estland og Letland. Ifølge FN er der større risiko for at blive voldtaget, overfaldet, myrdet eller udsat for røveri i Danmark end på Vestbalkan. Børnedødeligheden er også højere i Baltikum end mange steder på Vestbalkan, og selv om Jugoslavien aldrig vil genopstå, har de sidste par år vist udviklingen af, hvad der er blevet kaldt en 'Jugosfære'. En region, der dækker over det gamle Jugoslavien samt lande som Albanien, og hvor mange af de bånd, der blev kappet i 1990'erne, nu er ved at blive genoprettet - og ikke kun blandt de kriminelle, der altid har arbejdet på kryds og tværs af landegrænser.

Den legitime handel mellem de 
seks lande i eks-Jugoslavien er i dag intens. De største markeder for bosniske eksportvarer er Kroatien og Serbien, hvor henholdsvis 17,2 pct. og 14 pct. af alle landets varer havner. De to lande, der i 1992 invaderede Bosnien, står nu for 17,1 pct. og 10,6 pct. af landets import. En stor del af Kosovos handel er enten med Serbien eller Montenegro. Slovenske supermarkeder som Konzum, Delta og Mercator er nu at finde i alle nabolandene.

Kulturlandskabet er også blevet mere og mere regionalt end i årene efter 1990, hvor det kun var gamle partisansange, der kunne forene folk. Tv-kanalen Pink Television sender fra Beograd til alle regionens lande. Tv-programmer som Big Brother har deltagere fra alle regionens lande. Og popstjerner som kroatiske Severina og bosniske Damir Imamovic Trio optræder nu for fulde huse i Beograd, noget, der ville være utænkeligt for få år siden.

Mere højkulturelt er www.knizevnost.org, en hjemmeside for litteraturudgivelser som henvender sig til læsere fra hele regionen, og sidste sommer lokkede reklameskilte i Beograd folk til Kroatiens kystlinje et tilbud, som omkring 100.000 serbiske turister tog imod, flere end de 88.000, der gæstede Kroatien i 2008.

Paradoksalt nok er tidligere diskussioner om et Storalbanien taget i betragtning det intra-albanske forhold - 'Albanosfæren' om man vil svagere end Jugosfæren og endnu ikke en del af den. For eksempel er kun ganske få kosovoalbanske produkter i dag til salg i Albanien og vice versa. Bøger udgivet i Pristina er stadigvæk svære at finde i Tiranas boghandler pga. pres fra Albaniens trykkerilobby. Men her er der også undtagelser: Turister flokkes fra Kosovos heder til Albaniens kystlinje om sommeren. Kystbyen Durres, der nu kun er få timers kørsel fra Kosovo ad en nybygget motorvej, er et særligt tilløbsstykke; og det kosovoalbanske firma PTK købte i 2009 Albaniens fjerde største mobilnetværk. Prominente kosovoalbanske forretningsfolk har tætte forbindelser til Albanien og omvendt.

\section{Den lange EU-vej}

Denne situation synes som nævnt at passe de fleste regeringschefer i Europa ganske godt. Regionen ser ud til at være på den langsommelige vej mod EU-medlemskab, men dog ikke så hurtigt, at deres indlemmelse kan skade Lissabon-projektet eller give problemer for regeringer, som nu skal gå til valg med mere og mere udvidelsesskeptiske vælgere. Alle EU-lande står officielt ved erklæringen fra topmødet mellem EU og regionens lande i Thessaloniki den 21. juni 2003, hvor det blev besluttet, at EU ville give al mulig 'støtte' til regionens 'forberedelser med henblik på fremtidig integration i de europæiske strukturer' og - $\mathrm{i}$ sidste instans - medlemskab af Unionen. 
Ved Thessaloniki-topmødet fik Europa-Kommissionen til opgave at overvåge landenes forberedelse til EU-medlemskab. Udvidelsesprocessen blev delt ind i skridt, og det enkelte lands fremgang mht. disse skridt afhang af, om det opfyldte krav, der stilles af EU inden for forskellige fagområder. Som Julie Herschend Christoffersen skriver: kriterierne "blev en vejledning for de tidligere kommunistiske lande til, hvordan et demokratisk land med markedsøkonomi skulle indrettes."

Et lands første skridt mod EUmedlemskab er en Feasibility Study, der analyserer regeringens evne til at starte forhandlinger om en Stabiliserings- og Associeringsaftale (SAA). Derefter følger forhandlingerne om indholdet i aftalen, der skal overstås, før SAA kan initialiseres. Denne beslutning træffes af Europa-Kommissionen. Herefter overdrages aftalen til EU-landene, der skal godkende SAA'en. Kun herefter kan landet ansøge om medlemskab, hvorefter kandidatstatus skal tildeles, før forhandlingerne om medlemskab kan åbnes. Som beskrevet af Miroslav Lajcjak, den slovakiske udenrigsminister: "Vi har taget en gulerod og snittet den i forskellige små stykker." Idéen var, at tilbuddet om et fremtidigt medlemskab, ville gøre landene villige til at gennemføre tilsvarende reformprocesser, med andre ord at spise den metaforiske gulerod én skive ad gangen.

Men de sidste par år har vist, at ikke alle EU medlemslande forstår Thessaloniki-erklæringen på samme måde. Fraktionerne er ikke altid klare eller faste. Udenrigsministerier hævder, at alle EU-landene står ved Thessaloniki-erklæringen, men graver man lidt dybere og tales der mere privat (selv med udenrigsministre), kommer en anden virkelighed til syne. Nogle lande ønsker, at processen kunne speedes op, heriblandt de umiddelbare nabolande og måske også Sverige og Østrig. De $\varnothing n s k e r$ at give regionen al mulig hjælp, og det svenske EU-formandskab så landets udenrigsminister Carl Bildt rejse Vestbalkan tynd på en måde, som hans kolleger i dag ikke gider.

En anden gruppe er yderst tilfreds med den langsommelige march. Denne gruppe menes at inkludere Tyskland, Holland, Belgien og Frankrig. For disse lande er det sætningen 'i sidste instans' i Thessaloniki-erklæringen, der er vigtigst. Mange af dem bekymrer sig om konsekvenserne af en videre udvidelse af EU samt regionens vedvarende mangel på kompromiskultur, der er så vigtig for at få EU til at fungere. Ved at uofficielt møde i Litauen tidligere på året argumenterede Angela Merkels nærmeste rådgivere efter sigende imod en hurtig indlemmelse af Vestbalkan. Manglen på kompromiskultur kunne give EU's udenrigspolitiske ambitioner et dødsstød i og med, at landene ville kunne skabe et veto-nedlæggende, 
blokerende flertal for beslutninger. Der er specielt frygt for, at Serbien ønsker at blokere for Kosovo. Det er også lande som Holland og Belgien, der har insisteret på, at betingelsen om fuldt samarbejde med Det Internationale Krigsforbrydertribunal vedrørende det tidligere Jugoslavien (ICTY) skal være opfyldt, inden der kan blive tale om indgåelse af SAA med landene på Vestbalkan.

\section{Skifter side fra sag til sag}

Endelig er der en tredje gruppe af lande, der skifter side mellem de to hovedgrupper afhængig af konteksten. Således støtter lande som Danmark og England regeringerne i Tyskland og Holland, når det gælder om at stille skrappe krav til regionens ledere, fx når det kommer til ICTY, men mener modsat disse, at regionen burde blive en del af EU, når de er parate. Koalitioner og grupperinger skabes på kryds og tværs.

Som i alle andre EU-spørgsmål er alle medlemslande ikke lige magtfulde, når det drejer sig om udvidelsessagen. De nye medlemslande, der er mest interesserede i en hurtig udvidelse, er også de medlemslande, der har mindst indflydelse i EU. Dette gælder blandt andet Ungarn, Bulgarien og Rumænien, men til en vis grad også Østrig og Grækenland. Gamle medlemslande som England og Danmark er åbne over for en videre udvidelse, men vil ikke - idet de begge står uden for eurozonen og England endvidere uden for Schengensamarbejdet - skulle betale for de økonomiske eller andre konsekvenser af en yderligere udvidelse, som vil være tilfældet med Tyskland og Frankrig. England har derfor også tabt indflydelse på udvidelsesspørgsmålet. Det betyder, at lande som Tyskland og Frankrig står særdeles stærkt, når det kommer til udvidelsesspørgsmålet, og i begge lande er der større politisk pres for ikke at skynde sig. Frankrig skal bekræfte enhver udvidelse med en folkeafstemning, hvilket er en politisk barriere for selv udvidelsesivrige politikere.

I Tyskland er der begrænset opbakning, specielt efter Grækenlands økonomiske krise, som kan komme til at koste den tyske skatteborger dyrt. Hvis Grækenland efter næsten 30 års EU-medlemskab fortsat ligner et land på Vestbalkan, hvilke forhåbninger kan der så være til Makedonien eller Albanien i det geografiske Balkan? Disse lande har kun en brøkdel af Grækenlands bruttonationalprodukt. Skal den tyske skatteborger også være parat til at betale for deres klientelisme, småkriminalitet og korruption? Sådanne paroler genvælges tyske politikere ikke på. Så på trods af den fremgang, der har været i regionen, er det derfor svært at se dens reelle march mod EU.

Hertil kan lægges de store problemer med at implementere Lissabon- 
traktaten. Frem for at være en selvregulerende mekanisme har det vist sig, at traktatens bestemmelser og institutionelle nyskabelser skal fortolkes og videre forhandles. Indtil Lissabon-traktaten var EU's udenrigspolitik delt mellem Europa-Kommissionen, hvor der har siddet en kommissær for eksterne forbindelser, og Rådet, hvorfra EU's høje repræsentant for den fælles udenrigsog sikkerhedspolitik, Javier Solana, har rejst rundt i verden for at repræsentere EU's synspunkter. De to funktioner er nu samlet hos den nye udenrigsrepræsentant, som også skal skabe en slags EU's udenrigsministerium.

Men hvilke beføjelser den nye udenrigsrepræsentant, britiske Catherine Ashton, har, står endnu ikke klart. Hvordan udenrigstjenesten skal organiseres ligger ikke fast endnu, og forholdet til Vestbalkan svæver også i det uvisse. Er det udenrigsrepræsentantens ansvar at varetage relationerne, eller tilkommer det den nye kommissær for udvidelse og naboskabspolitik? Da Ashton besøgte Vestbalkan på sin første officielle udenlandske rejse, blev hun kritiseret for at tage arbejde fra EU's udvidelseskommissær i stedet for at fokusere på større problemer som i Mellemøsten. Indtil disse forhold er afklaret, vil der være begrænset fælles EU- fokus på Balkan. Umiddelbart kan konsekvenserne af en rodet EU-aktivitet bedst ses i Bosnien, hvor EU har forholdt sig tøvende over for provokationer fra Milorad Dodik, lederen af Republika Srpska, der ønsker uafhængighed for den serbiske del af landet i direkte modstrid med Dayton-aftalen, der bragte krigen til ophør i 1995.

\section{Bilateralisering - på godt og ondt}

Den nuværende situation har ført til det, som kan kaldes en 'bilateralisering' af forholdet mellem en række EU-lande og lande på Vestbalkan. Der har naturligvis altid været stærke bilaterale forhold mellem regionen og visse EU-lande, især dem tæt på regionen: Østrig, Grækenland, Italien og Bulgarien - eller Slovenien, som var en del af Jugoslavien.

I dag er det dog en anden slags bilaterale forhold end tidligere, der gør sig gældende. Som følge af, at der ikke findes et troværdigt, fælles europæisk fodslag over for regionen, søger mange af landene på Vestbalkan ly og beskyttelse i bilaterale forhold til EU-lande. Mange EU-medlemmer søger enten stærke bilaterale forhold til regionens lande, som det er tilfældet med Italien og Albanien, eller lader deres bilaterale stridigheder undergrave en fælles EU-politik, som Grækenlands veto imod Makedoniens ønske om medlemskab af EU.

Denne bilateralisering har to konkrete konsekvenser for Vestbalkan. I det tilfælde, at landene finder en EU-partner, er der større chance for, at deres forsøg på reformer aner- 
kendes, selv om de ikke har opnået de nødvendige standarder. Et par eksempler er Italiens varme fortale for Albanien og Frankrigs særinteresse for Serbien. I EU-regi går disse to store EU-lande tit til forsvar for regeringerne i Tirana og Beograd, samtidig med at deres ambassadører i de to hovedstæder hvisker i lokalpolitikernes ører, at deres interesser vil blive varetaget. Konsekvensen er derfor, at reformiveren formindskes betydeligt.

Men bilateraliseringen går også den anden vej - dog med samme konsekvens for vigtige reformprocesser. Når EU-medlemmer blokerer for udenforstående landes fremmarch mod EU-medlemskab, som det fx var tilfældet med Slovenien, der brugte sin status som EU-medlem til at få grænsedragninger i Kroatien ændret, eller Grækenlands vedholdende veto af Makedonien, er sagen anderledes: Frem for at landene har venner i EU, har de nu fjender. Konsekvensen af den bilaterale dominans er dog den samme: Landene i regionen mister interessen for reformer, idet der ikke længere kan garanteres en reel fremgang. Hvorfor gennemføre kostbare reformer, hvis det ikke fører til noget?

Et godt eksempel er Makedonien, der længe er blevet forhindret i den videre integrationsproces af forskellige græske regeringer pga. af striden om landets officielle navn. Selv om landet har gjort store frem- skridt, har det siden 2008 stået klart, at reformiveren er noget slækket. I sin rapport fra 2008 sagde EuropaKommissionen, at der var vedvarende problemer med korruption og retssystemets uafhængighed. Der er ingen tvivl om, at det udskudte medlemskabsperspektiv har gjort sit til at formindske regeringens reformiver.

\section{Uliberale demokrater}

Det udskudte medlemskab - forstærket af den stigende bilateralisering - har haft en anden konsekvens: I stedet for at udvidelsesprocessen og den dertilhørende konditionalitet kun skaber positive, indenrigspolitiske ændringer, har man i de sidste par år set udviklingen af en ny generation af uliberale demokrater, der er kommet til magten i flere af regionens lande og har forstået, hvordan de kan manipulere EU's krav uden reelt at gennemføre de nødvendige reformer. Ledere som Sali Berisha i Albanien, Milorad Dodik i Republika Srpska i BosnienHerzegovina, Nikola Gruevski i Makedonien, Milo Djukanovic i Montenegro og Boris Tadic i Serbien, har udviklet en helt anden tilgang til EU's integrationsproces end deres kolleger i Øst- og Centraleuropa.

Hvor ledere i Polen, Tjekkiet, Slovakiet og Ungarn altid troede, at deres landes medlemskab var lige om hjørnet, og derfor regnede med at kunne høste valgmæssigt, når deres lande blev optaget i EU, tror de fle- 
ste ledere på Vestbalkan, at det enten vil tage for lang tid, før de bliver medlemmer - og derfor ikke har meget at arbejde for - eller, at deres venner i EU-kredsen nok skal varetage deres interesser, og at de derfor heller ikke behøver at gennemføre de reformer, Europa-Kommissionen kræver.

Det faktum, at medlemskabsperspektivet er længere væk, og at regionens ledere enten kan håbe på at blive hjulpet af deres venner i EU, eller blive blokeret af deres fjender, har gjort dem uinteresserede i reformer og betydet, at mange bruger udvidelsesprocessen til at underminere deres politiske modstandere og dermed styrke deres egen magtposition.

På trods af mange af landenes fremgang er der nu tegn på, at regionen bliver 'post-sovjetiseret', frem for 'europæiseret'.

Dette kan ses på en række forskellige områder. Næsten alle regionens ledere har i de seneste par år forsøgt at centralisere deres magtstruktur og er næsten alle blevet beskyldt for at forgylde en snæver kreds af støtter, familiemedlemmer eller partisoldater. I en rapport fra Verdensbanken i 2006 beskrives albansk politik som gennemsyret af korruption, klientelisme, mangel på lov og orden, problematiske regeringsprocesser samt en ufri presse. Det samme kan siges at være tilfældet i mange af de andre lande.

Som en højtstående embedsmand fra regionen udtrykker det: "Vore politikere har forstået, hvordan de kan manipulere EU's budskaber. Selv om EU er kritisk, bliver det hurtigt af den lokale presse omfortolket til en lovprisning af de siddende regeringer på foranledning af deres politiske venner. Og regeringerne fortsætter den overfladiske tilgang til reformer." Frem for at hjælpe landene af med den slags politik og sætte vind i reformsejlene, som det var tilfældet i Øst- og Centraleuropa, har udvidelsesprocessen i de sidste par år været med til det modsatte. Det er i hvert fald befolkningernes dom. 49 pct. af kroaterne og 38 pct. af bosnierne mener, at EU-medlemskab for deres to lande 'vil tilgodese dem, der allerede er på toppen'.

\section{EU er ikke alene}

Selv når alle EU-landene kan være enige om en politik, er de instrumenter, der er til rådighed for $\mathrm{EU}$, mindre og mindre effektive. Politikere kan 'spinne' sig ud af kritik fra EU og er ikke længere sårbare over for dårlige rapporter.

Europa-Kommissionen har også svært ved at bruge penge som pressionsmiddel. Den finansielle assistance fra EU til regionen gik fra 1999 til 2006 igennem de såkaldte CARDS-program, som i 2007 blev afløst af det såkaldte IPA-program. Alene i 2008 støttede EU Vestbalkans lande med 650 millioner euro gennem IPA-programmet. Det me- 
ste af støtten er fokuseret på institutionelle reformer samt reformer af det juridiske system, dvs. områder, hvor fremskridt ikke kun gavner landene, men også EU, der ønsker et udbredt politisamarbejde med Vestbalkan. Men som Valentin Inzko, EU's særlige repræsentant i Bosnien, udtrykker det: "Det er ikke sådan, at jeg kan straffe nogen ved at tilbageholde ressourcer. EU-penge bliver brugt til at hjælpe os selv. Tilbageholdelse af penge vil kun gøre vores arbejde sværere." Pengene bliver ikke hovedsageligt brugt på genopbygning og udvikling af landenes infrastruktur - områder, hvor fratagelse af støtte vil have en klar effekt.

I takt med at EU's udvidelsesproces har mistet sin glans og EuropaKommissionens økonomiske instrumenter er blevet mindre effektive som pressionsmiddel, er det muligt at se andre ikke-EU-landes stigende indflydelse på Vestbalkan. Det drejer sig ikke om USA, der længe var en magtfaktor på Vestbalkan, men nu kun spiller en mindre rolle. De lande, hvis indflydelse i regionen i dag er stigende (på EU's bekostning), er Rusland, Tyrkiet og Kina. De tre lande har forskellige forhold til landene på Vestbalkan, forskellige målsætninger og anvender forskellige instrumenter for at opnå deres mål.

Rusland har aldrig set på Vestbalkan med samme øjne, som Moskva betragter landene i det tidligere Sovjetunionen. Regionen er siden Koso- vo-krigen blevet anset som Vestens interessesfære. Men regeringen i Moskva har ikke været bleg for at stikke en kæp i EU's hjul eller bruge $\varnothing$ konomiske midler til at underminere landenes tilnærmelse til EU. Specielt forholdet til Serbien forbliver stærkt, og der har sågar været tale om en russisk militærinstallation i Serbien. Det kan godt være, som mange i EU antager, at Serbien ikke har anden fremtid end som medlem af EU, men en stolt diplomatisk tradition, en historie som neutralt land og konflikten med Vesten om Kosovos uafhængighed betyder, at Serbiens regering ikke føler, at de behøver at træffe et enten/eller valg, og at der er en tredje vej for landet. En slags neo-Titoisme, i hvert fald på kort sigt. Sandt eller ej, så er det en idé, Ruslands regering er mere end tilfredse med at støtte - om ikke for andet, så for at underminere EU's råderum på Vestbalkan.

Tyrkiet har været en mere rolig og konstruktiv partner og har nære forhold til Bosnien, Albanien og Makedonien. Handlen mellem Tyrkiet og Albanien er stigende år for år. Præsident Gul, premierminister Erdogan og udenrigsminister Davutoglu var alle på besøg i Tirana i 2009. Handlen mellem Ankara og Sarajevo er også stigende lige som forholdet mellem Tyrkiet, Makedonien og Serbien.

Den nyeste faktor er dog regionens forhold til Kina. Handlen mellem regionen og Kina er stærkt sti- 
gende. I 2008 steg handlen mellem Albanien og Kina med næsten 30 procent og er i dag landet tredjestørste handelspartner. Handlen med Tyrkiet er også stigende, men ikke i så høj grad som med Kina. Det samme mønster kan ses i hele regionen. Serbiens præsident, Boris Tadic, var sidste år i Kina i spidsen for en handelsdelegation, der havde til mål at øge den allerede voksende kinesiske investering i Serbien. Albaniens Sali Berisha fulgte ham i hælene.

Kinas handel med regionen blegner i forhold til samhandlen med EU, men kan på længere sigt underminere Vestbalkans vækst. Modsat investeringer fra de europæiske lande er Kina interesseret i samarbejde om store industriprojekter, der er mere givende for regionens politikere, der kan bruge investeringerne til at tilgodese allierede i erhvervslivet.

Den kinesiske bilfabrikant Dongfeng og Serbiske FAP fra byen Priboj har netop indgået en aftale om et fælles projekt, og Kina besluttede i februar 2010 at investere 800 millioner euro i et serbisk atomkraftværk. Der er få tilsvarende europæiske investeringer. Det kinesiske guld lokker ikke kun landene på Vestbalkan men også EU-medlemmer. I januar, da den græske regering indså konsekvenserne af landets økonomiske katastrofe, blev Kina gennem investeringsbanken Goldman Sachs tilbudt refinansiering af en del af statsgælden.

Men situationen i Vestbalkan er anderledes. I alle tre tilfælde - Rusland, Kina og Tyrkiet - er der tale om en alternativ kilde til EU for handel og politisk samarbejde, der for regionens ledere er mere attraktiv og med færre betingelser end støtte fra EU og samhandel med europæiske virksomheder. Der er måske ingen 'russisk vej' for Serbien eller en genoprettelse af Albaniens historiske bånd til Kina. Og Tyrkiet vil ikke kunne hjælpe Bosnien. Men på et tidspunkt, hvor der er tvivl om Thessaloniki-erklæringens aktualitet og den manglende reformiver i regionen, kan den Balkanpolitik, der i dag føres af Rusland, Tyrkiet og Kina være med til yderligere at underminere regionens EU-rejse.

\section{Kræves: En ny udvidelsespolitik}

På trods af den ortodoksi, der hersker i EU-kredse i Bruxelles, (hvor enhver kritik af EU's politik tit ses som suspekt og ondsindet) er det ikke forbigået alle, at udvidelsesiveren i EU er blevet slækket og at integrationslysten i landene på Vestbalkan er faldet tilsvarende. Denne indsigt fik for nogle år siden EU til at sætte fokus på adgang for regionens borgere til det grænseløse Schengen-område.

Idéen var at bruge rejselysten specielt blandt unge i regionen - til at presse regionens regeringer til at gennemføre yderligere reformer. Frem for blot at få et skulderklap af Europa-Kommissionen, når refor- 
mer blev gennemført, var idéen, at afskaffelsen af visumkravet for flere af landene fra Vestbalkan ville sætte gang i reformer - specielt i politiet og retssystemet.

På mange måder har det vist sig at lykkedes. Løftet om afskaffelse af visum for indrejse til Schengen-området fik sat gang i reformerne i en sådan grad, at borgere i Makedonien, Serbien og Montenegro i dag har fået visumfri adgang til dele af EU. Der vil stadig være krav om visum for borgerne fra Bosnien-Hercegovina og Albanien; men det formodes, at disse to lande snart vil følge efter.

Og det er netop med denne succes, EU kan finde en mulig ny politik over for Vestbalkan, der kan løse de problemer, der gør sig gældende i dag. Men først er det vigtigt at analysere, hvorfor løftet om en lempelse af visumreglerne skabte fremgang i en række lande og sektorer, hvor reformiveren har været begrænset, eller hvor storpolitiske problemer har stået i vejen for teknokratiske fremskridt.

Der er tre hovedårsager: For det første var der en reel, populær gevinst i sigte med alt reformbesværet: Rejsefrihed i EU for regionens borgere. For det andet var der lige konkurrence mellem regionens lande. Der kunne derfor laves sammenligninger mellem de forskellige landes fremskridt, og presset på de regeringer, der ikke gennemførte reformer hurtigt nok, blev automatisk øget.
Den tredje årsag til successen var de klare, simple betingelser, og ved hjælp fra græsrodsbevægelser blev alle de relevante dokumenter gjort tilgængelige for offentligheden.

For at sætte skub i udvidelsesprocessen er det nu nødvendigt at finde tilsvarende områder i EU's lovsamling, som er tilpas attraktive for borgere på Vestbalkan, og hvor der kan udarbejdes klare betingelser, som kan tilbydes regionens lande på samme tid (for at opnå konkurrenceeffekt) og som kan finde sted, før forhandlingerne om medlemskab kan åbnes. Dette vil ikke være let, men der burde være nogle åbenlyse emner, som $\mathrm{fx}$ adgang til markedet for tjenesteydelser, altså servicedirektivet.

For at gennemføre en sådan strategi uden at ændre for meget i EU's udvidelsesproces (hvilket ville møde stor modstand), skal landene i regionen først tildeles kandidatstatus. Ud over Kosovo og Bosnien burde det være inden for rækkevidde.

Til de lande, der er bange for at tildelingen af kandidatstatus automatisk vil lede til forhandlinger om medlemskab kort tid derefter, kan der henvises til erfaringer fra Bulgarien, Letland, Rumænien og Tyrkiet. Alle disse lande fik kandidatstatus, længe før de reelle forhandlinger begyndte. Tyrkiet fik kandidatstatus i 1999, men begyndte først forhandlinger i 2005. Reformprocesserne blev for alvor sat i gang i denne periode. 
Et yderligere skridt burde tages med formuleringen af en ny udvidelsespolitik. Der burde sættes mere fokus på at gøre udvidelsespolitik til udviklingspolitik. En stor del af udvidelsespolitikken berører områder, der er for langt væk fra almene borgere. Selv hvis regionens lande får adgang til markedet for tjenesteydelser, vil det være tilfældet. Som beskrevet ovenfor går en stor del af EU's støtte til institutionelle reformer, der kun langsomt kommer befolkningerne til gode, og som ikke let kan tages fra regeringerne som straf for at spænde ben for reformer, uden at det går ud over EU selv (og bliver erstattet af investeringer fra andre lande som fx Kina). Der er derfor brug for 'en anden slags' penge. Ressourcer, der mere direkte kan komme folk til gavn samt give EU et mere effektivt pressionsmiddel over for regionens ledere.

EU har gode erfaringer internt med brugen af strukturfonden og samhørighedsfonden, der har til mål at nivellere forskelle mellem EU-landene. Brugen af den slags fonde i lande, der har fået kandidatstatus, kunne gøre en meget stor forskel. Der er allerede gode erfaringer fra lande som Polen og Rumænien; men effekten vil være endnu større på Vestbalkan, når man tager den uudviklede industri- og landbrugssektor i betragtning.

Vigtigst af alt kommer penge fra strukturfonden og samhørighedsfonden befolkningen direkte til gode - og det er muligt at se konsekvenserne af EU-investeringer, idet pengene ikke kun går til institutionelle reformer, men også til veje, infrastruktur, landbrug, erhvervsudvikling osv.

Hvis tildelingen af penge fra disse fonde kan gå hånd i hånd med, at EU overtager ansvaret for færdiggørelse af reelle udviklingsplaner i regionen, er det så meget desto bedre. I dag findes der kun få planlægningsprocesser i de forskellige regeringer. Verdensbanken og UNDP, der hver især har forsøgt at indføre nye planlægningsprocesser, har ikke haft megen succes. Der er i dag i regionen adskillige årlige planlægningsprocesser, men ingen, der reelt bliver fulgt at de forskellige regeringer.

Hvis adgang til strukturfonden og samhørighedsfonden bliver kædet sammen med formuleringen af EUstøttede, flerårige nationale udviklingsplaner, vil det være muligt ikke kun at forbedre allokeringen af landenes egne ressourcer, men også af EU's midler.

\section{Kosovo som undtagelse}

En sådan ny politik skulle kunne virke i alle lande bortset fra Kosovo, og den vil ikke være tilstrækkelig i Bosnien. Så længe der er fem EU-lande, der ikke godkender Kosovos uafhængighed, vil det ikke være muligt at give landet kandidatstatus og dermed begynde at iværksætte den nye 
strategi. I Bosnien burde det være muligt inden længe at bringe landet til et punkt, hvor kandidatstatus kan overvejes; men det vil ikke i sig selv løse den etnisk-territoriale konflikt, der ligger til grund for de nuværende politiske problemer. Her skal der andre midler til; men en ny politik, som her beskrevet, kan afhjælpe nogle af de problemer, udvidelsesprocessen på nuværende tidspunkt står overfor og skabe nye rammebetingelser for hele regionens rejse mod EU-medlemskab.

Der har været megen fremgang i regionen siden krigen i slutningen af 1990 'erne. Det er dog vigtigt, at EU ikke hviler på laurbærrene, men ser de reelle udfordringer, regionen i dag står overfor.

Hvor hårdt de end arbejder i regionen, mener mange eksperter, at omverdenens problemer, politiker- nes trakasserier samt eliternes uansvarlighed kan føre Vestbalkan ud over afgrundens rand. Dermed er der risiko for, at regionen og måske Balkan bliver alt andet end kedelig. EU har mange mulige redskaber tilbage i værktøjskassen for at undgå dette. Det gælder bare om at udvikle en modificeret udvidelsespolitik, der gør, at EU kan bruge de forskellige værktøjer på det rigtige tidspunkt.

EU's udvidelse er til gavn for såvel de nye, som for de gamle medlemsstater samt for hele EU, så det er vigtigt at fortsætte rejsen til Europa, selv om det skal ske ad nye veje.

Daniel Korski er Balkan- og Irakekspert ved European Council on Foreign Relations. Han har varet udstationeret begge steder. 
TEMA: VESTBALKAN OG EU

\begin{tabular}{|c|c|c|c|c|}
\hline & Albanien & $\begin{array}{l}\text { Bosnien- } \\
\text { Hercegovina }\end{array}$ & Kosovo & Kroati \\
\hline Areal & $28.748 \mathrm{~km}^{2}$ & $51.564 \mathrm{~km}^{2}$ & $10.908 \mathrm{~km}^{2}$ & 56.538 \\
\hline Hovedstad & Tirana & Sarajevo & Prishtina & Zagr \\
\hline Indbyggertal & 3,2 mio. & 3,9 mio. & 2,13 mio. & $4,6 n$ \\
\hline Befolkningsgrupper & $\begin{array}{l}\text { albanere } 95-98 \% \text {. } \\
\text { Mindretal af } \\
\text { grækere, } \\
\text { makedonere, } \\
\text { romaer, serbere, } \\
\text { montenegriner } \\
\text { m.fl. }\end{array}$ & $\begin{array}{l}\text { bosniakker } 44 \% \text {, } \\
\text { serbere } 31 \% \text {, } \\
\text { kroater } 17 \% \text {, } \\
\text { øvrige } 8 \%\end{array}$ & $\begin{array}{l}\text { albanere } 88 \% \text {, } \\
\text { serbere } 7 \% \text {, } \\
\text { øvrige } 5 \%\end{array}$ & $\begin{array}{l}\text { kroater } \\
\text { desude } \\
\text { bosnia } \\
\text { sloven } \\
\text { italien } \\
\text { ungare }\end{array}$ \\
\hline Sprog & $\begin{array}{l}\text { albansk, græsk } \\
\text { samt flere } \\
\text { mindretalssprog }\end{array}$ & $\begin{array}{l}\text { bosnisk, serbisk, } \\
\text { kroatisk }\end{array}$ & albansk, serbisk & $\begin{array}{l}\text { kroatis } \\
\text { største } \\
\text { mindre } \\
\text { serbisk }\end{array}$ \\
\hline Religion & $\begin{array}{l}\text { muslimer } 70 \% . \\
\text { ortodokse kristne } \\
20 \% \\
\text { katolikker } 10 \%\end{array}$ & $\begin{array}{l}\text { muslimer, } \\
\text { ortodokse kristne, } \\
\text { katolikker, et lille } \\
\text { antal protestanter }\end{array}$ & $\begin{array}{l}\text { flertallet } \\
\text { muslimer, } \\
\text { mindretal af } \\
\text { katolikker og } \\
\text { ortodokse kristne }\end{array}$ & $\begin{array}{l}\text { flertall } \\
\text { katolik } \\
\text { mindre } \\
\text { ortodo } \\
\text { muslin }\end{array}$ \\
\hline BNP/capita (PPP) & 6.000 USD & 6.500 USD & 2.300 USD & 18.30 \\
\hline $\begin{array}{l}\text { Diverse sektorers } \\
\text { andel af BNP }\end{array}$ & $\begin{array}{l}\text { landbrug } 22 \% \text {, } \\
\text { industri } 27 \% \text {, } \\
\text { service og andet } \\
51 \%\end{array}$ & $\begin{array}{l}\text { landbrug og } \\
\text { fiskeri } 10 \% \text {, } \\
\text { industri og } \\
\text { byggeri } 24 \% \text {, } \\
\text { service og andet } \\
66 \%\end{array}$ & $\begin{array}{l}\text { landbrug } 20 \% \\
\text { industri } 20 \% \\
\text { service og andet } \\
60 \%\end{array}$ & $\begin{array}{l}\text { landbr } \\
\text { skovbr } \\
\text { fiskeri } \\
\text { industr } \\
\text { service } \\
61 \%\end{array}$ \\
\hline $\begin{array}{l}\text { Vigtigste } \\
\text { samhandelspartnere }\end{array}$ & $\begin{array}{l}\text { Italien, } \\
\text { Grækenland, } \\
\text { Kina, Tyskland }\end{array}$ & $\begin{array}{l}\text { Kroatien, Serbien, } \\
\text { Montenegro, } \\
\text { Tyskland, Italien, } \\
\text { Slovenien }\end{array}$ & $\begin{array}{l}\text { eksport: CEFTA- } \\
\text { landene (Polen, } \\
\text { Tjekkiet, } \\
\text { Slovakiet, } \\
\text { Ungarn, } \\
\text { Slovenien, } \\
\text { Rumanien, } \\
\text { Bulgarien) } \\
\text { import: EU, } \\
\text { Makedonien, } \\
\text { Serbien, Tyrkiet }\end{array}$ & $\begin{array}{l}\text { Italien, } \\
\text { Herces } \\
\text { Tyskla } \\
\text { Ruslan }\end{array}$ \\
\hline Status ifht. NATO & medlem & $\begin{array}{l}\text { deltager i } \\
\text { Partnerskab for } \\
\text { Fred-programmet }\end{array}$ & & medler \\
\hline Status ifht. EU & $\begin{array}{l}\text { ansøgt om } \\
\text { medlemskab } 2009\end{array}$ & $\begin{array}{l}\text { har indgået en } \\
\text { Stabiliserings- og } \\
\text { Associeringsaftale } \\
\text { med EU }\end{array}$ & & kandid \\
\hline
\end{tabular}

Kilde: Lande i Lommeformat 


\begin{tabular}{|c|c|c|c|c|}
\hline en & Makedonien & Montenegro & Serbien & Slovenien \\
\hline $\mathrm{km}^{2}$ & $25.713 \mathrm{~km}^{2}$ & $13.812 \mathrm{~km}^{2}$ & $77.474 \mathrm{~km}^{2}$ & $20.253 \mathrm{~km}^{2}$ \\
\hline & Skopje & Podgorica & Beograd & Ljubljana \\
\hline & 2,06 mio. & 678.000 & 7,4 mio. & 2 mio. \\
\hline $\begin{array}{l}89 \% \text {, } \\
\text { n serbere, } \\
\text { kker, } \\
\text { re, } \\
\text { re, } \\
\text { re, romaer }\end{array}$ & $\begin{array}{l}\text { makedonere } 64 \\
\% \text {, albanere } 25 \% \text {, } \\
\text { tyrkere } 4 \%, \\
\text { romaer } 3 \%, \\
\text { øvrige } 4 \%\end{array}$ & $\begin{array}{l}\text { montenegrinere } \\
43 \% \text {, serbere } 32 \\
\% \text {, bosniakker } 8 \\
\% \text {, albanere } 5 \% \text {, } \\
\text { øvrige } 12 \%\end{array}$ & $\begin{array}{l}\text { serbere } 83 \% \text {, } \\
\text { ungarere } 4 \% \text {, } \\
\text { bosniakker } 2 \% \text {, } \\
\text { romaer godt } 1 \% \text {, } \\
\text { desuden kroater, } \\
\text { montenegrinere }\end{array}$ & $\begin{array}{l}\text { slovenere } 83 \% \text {, } \\
\text { serbere } 2 \% \text {, } \\
\text { kroater } 2 \% \text {, } \\
\text { bosniakker } 1 \% \text {, } \\
\text { desuden albanere, } \\
\text { ungarere, } \\
\text { italienere, romaer }\end{array}$ \\
\hline $\begin{array}{l}\mathrm{k}, \\
\text { talssprog: } \\
\text {, italiensk }\end{array}$ & $\begin{array}{l}\text { officielle sprog: } \\
\text { makedonsk, i } \\
\text { visse områder } \\
\text { albansk }\end{array}$ & $\begin{array}{l}\text { montenegrinsk, } \\
\text { serbisk, bosnisk, } \\
\text { albansk }\end{array}$ & $\begin{array}{l}\text { serbisk, } \\
\text { mindretalssprog: } \\
\text { ungarsk }\end{array}$ & $\begin{array}{l}\text { officielle sprog: } \\
\text { slovensk, i visse } \\
\text { områder italiensk, } \\
\text { ungarsk }\end{array}$ \\
\hline $\begin{array}{l}\text { ker, } \\
\text { kal af } \\
\text { sse kristne, } \\
\text { ler, } \\
\text { anter }\end{array}$ & $\begin{array}{l}\text { flertallet } \\
\text { ortodokse kristne, } \\
\text { stort mindretal af } \\
\text { muslimer, } \\
\text { katolikker }\end{array}$ & $\begin{array}{l}\text { ortodokse kristne } \\
74 \% \text {, muslimer } \\
18 \% \text {, katolikker } \\
4 \%\end{array}$ & $\begin{array}{l}\text { flertallet } \\
\text { ortodokse kristne, } \\
\text { mindre grupper } \\
\text { af muslimer og } \\
\text { katolikker }\end{array}$ & $\begin{array}{l}\text { katolikker } 58 \% \text {, } \\
\text { desuden } \\
\text { muslimer, } \\
\text { ortodokse kristne, } \\
\text { protestanter, } \\
\text { jøder }\end{array}$ \\
\hline USD & 9.000 USD & 9.700 USD & 10.900 USD & 29.600 USD \\
\hline $\begin{array}{l}\text { ig, } \\
\text { ug og } \\
7 \%, \\
\text { i } 32 \%, \\
\text { og andet }\end{array}$ & $\begin{array}{l}\text { land- og skovbrug } \\
11 \% \text {, industri } 27 \\
\% \text {, service og } \\
\text { andet } 62 \%\end{array}$ & $\begin{array}{l}\text { landbrug } 10 \% \text {, } \\
\text { industri } 20 \% \text {, } \\
\text { service og andet } \\
69 \%\end{array}$ & $\begin{array}{l}\text { landbrug } 11 \% \text {, } \\
\text { industri } 24 \% \text {, } \\
\text { service og andet } \\
65 \%\end{array}$ & $\begin{array}{l}\text { landbrug } 2 \% \text {, } \\
\text { industri } 34 \% \text {, } \\
\text { service og andet } \\
64 \%\end{array}$ \\
\hline $\begin{array}{l}\text { Bosnien- } \\
\text { ovina, } \\
\text { nd, } \\
\text { d, Østrig }\end{array}$ & $\begin{array}{l}\text { Serbien, } \\
\text { Tyskland, } \\
\text { Grækenland, } \\
\text { Italien, Bulgarien }\end{array}$ & $\begin{array}{l}\text { eksport: Bosnien- } \\
\text { Hercegovina, } \\
\text { Grækenland, } \\
\text { Italien, Serbien, } \\
\text { Slovenien } \\
\text { import: Østrig, } \\
\text { Kina, Tyskland, } \\
\text { Grækenland, } \\
\text { Italien, Serbien, } \\
\text { Schweiz }\end{array}$ & $\begin{array}{l}\text { eksport: Italien, } \\
\text { Bosnien- } \\
\text { Hercegovina, } \\
\text { Tyskland, } \\
\text { Makedonien } \\
\text { import: Rusland, } \\
\text { Tyskland, Italien, } \\
\text { Kina }\end{array}$ & $\begin{array}{l}\text { eksport: } \\
\text { Tyskland, Italien, } \\
\text { Kroatien, Østrig } \\
\text { import: Tyskland, } \\
\text { Italien, Østrig, } \\
\text { Frankrig }\end{array}$ \\
\hline 1 & $\begin{array}{l}\text { deltager i } \\
\text { Partnerskab for } \\
\text { Fred-programmet }\end{array}$ & $\begin{array}{l}\text { deltager i } \\
\text { Partnerskab for } \\
\text { Fred-programmet }\end{array}$ & $\begin{array}{l}\text { deltager i } \\
\text { Partnerskab for } \\
\text { Fred-programmet }\end{array}$ & medlem \\
\hline atland & kandidatland & $\begin{array}{l}\text { ansøgt om } \\
\text { medlemskab } \\
2008\end{array}$ & $\begin{array}{l}\text { ansøgt om } \\
\text { medlemskab } \\
2009\end{array}$ & medlem \\
\hline
\end{tabular}

